DOI:10.24946/IJPLS.20.18.00.00.211201

www.journalprenatalife.com

\title{
The image and role of the midwife in the ancient Greek and Byzantine art
}

By Dr. Maria Athanasekou, Art Historian

\section{Affiliations}

1. Hellenic Open University,

2. University of Macedonia,

3. Frederick University

\section{Abstract}

The purpose of this paper is to discuss the function and multifaceted role of the midwife in Greek culture as portrayed in art. Traditionally, midwifery has been recognized as a female occupation in every civilization and is one of the most ancient sciences or arts. Diachronically, the midwife has always been present during labour in order to help and support the pregnant woman. Midwifery is deeply linked to the very mystery of life and its advent to the world and has always been a well-respected profession. Most ancient Greek writers speak highly of midwives and Socrates himself proudly states that he is the son of a midwife. During Byzantine times the image of the midwife continues to gain respect and recognition. Her position is greatly estimated as deduced by the presence of midwives in Byzantine icons of the nativity of Christ. Through various works of art, this paper focuses on the image and social position of the midwife in Greek art, as well as her much appreciated profession. 
Key words: Midwifery, childbirth, nurse, art, iconography. Greece

Maternity and the bond between the mother and the child are among the most visited themes in art (Fig.1). Midwives have always been present during the effort of the mother to bring her baby to life and thus have a fundamental part in the mystery and miracle of life.

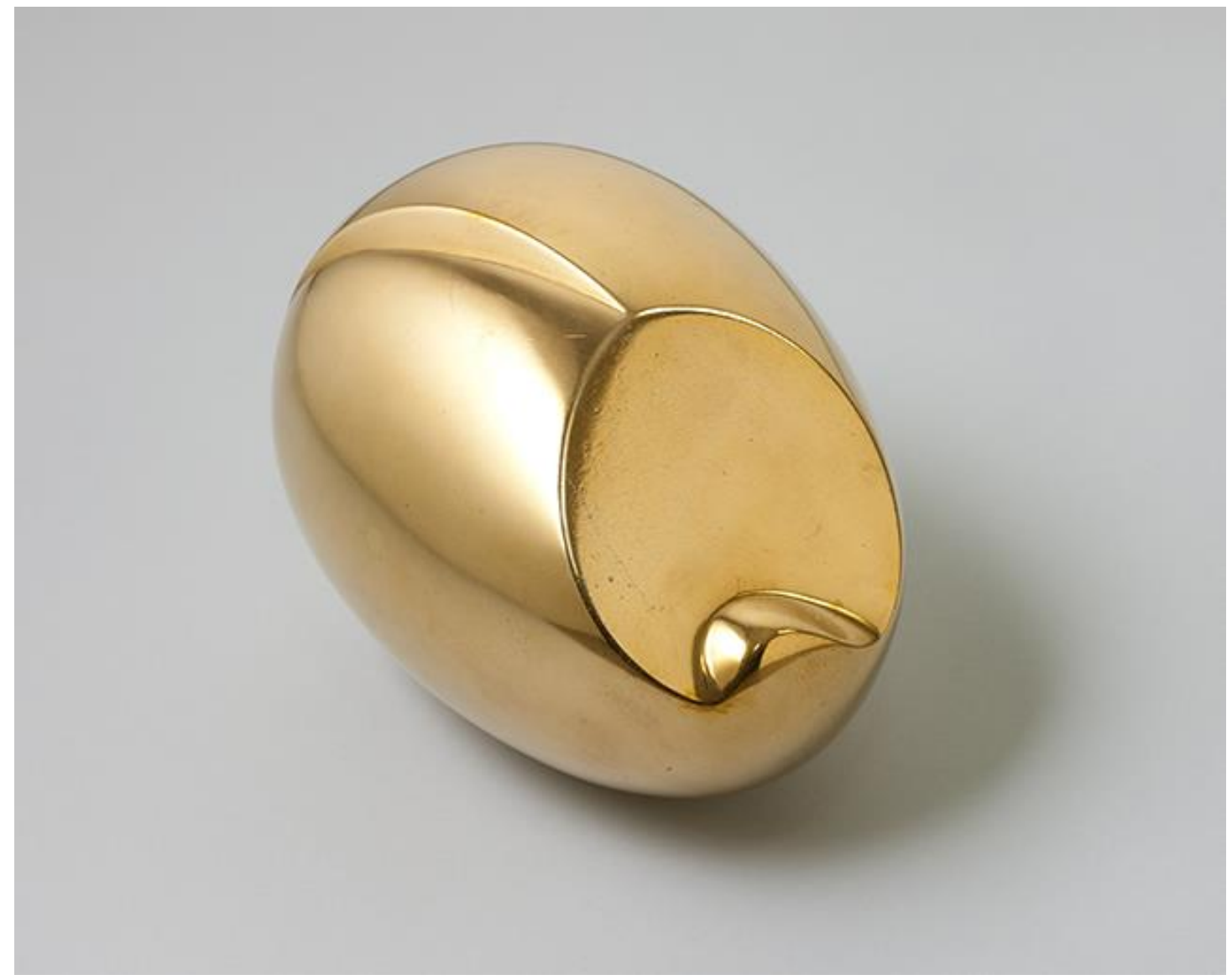

(Fig 1)

Midwifery is the health science and health profession that deals with pregnancy, childbirth, and the postpartum period (including care of the newborn) ${ }^{1}$, in addition to the sexual and reproductive health of women throughout their lives ${ }^{2}$.

Looking at the history of mankind, midwives have played a vital role in society that is beneficial to all members. They assisted women during labour and also helped

\footnotetext{
1 "Definition of Midwifery". Encyclopædia Britannica. Retrieved 7/10/ 2018.

2 "International Definition of the Midwife". International Confederation of Midwives. Retrieved $7 / 10 / 2018$.
} 
children to safely come to the light of life. Midwives have been depicted in art, though rarely, thus gaining a place as an iconographic subject in the History of Art.

Midwifes have been depicted and sculpted in early art. In five columns dealing with obstetrics and gynecology, the Ebers Papyrus, which dates from 1900 to 1550 BCE, attests to the high status of the profession of the midwife. In the Westcar papyrus, dating to $1700 \mathrm{BCE}$, descriptions of various styles of birth chairs are given as well as instructions regarding the confinement period of the woman who has just given birth. Bas reliefs in the royal birth rooms at Luxor and other temples also indicate the profound presence of midwifery in this civilization ${ }^{3}$. In Greco-Roman antiquity midwifery constituted a well-respected profession and comprised practitioners who were trained both in folk medical traditions and others who were considered physicians ${ }^{4}$ (Fig. 2).

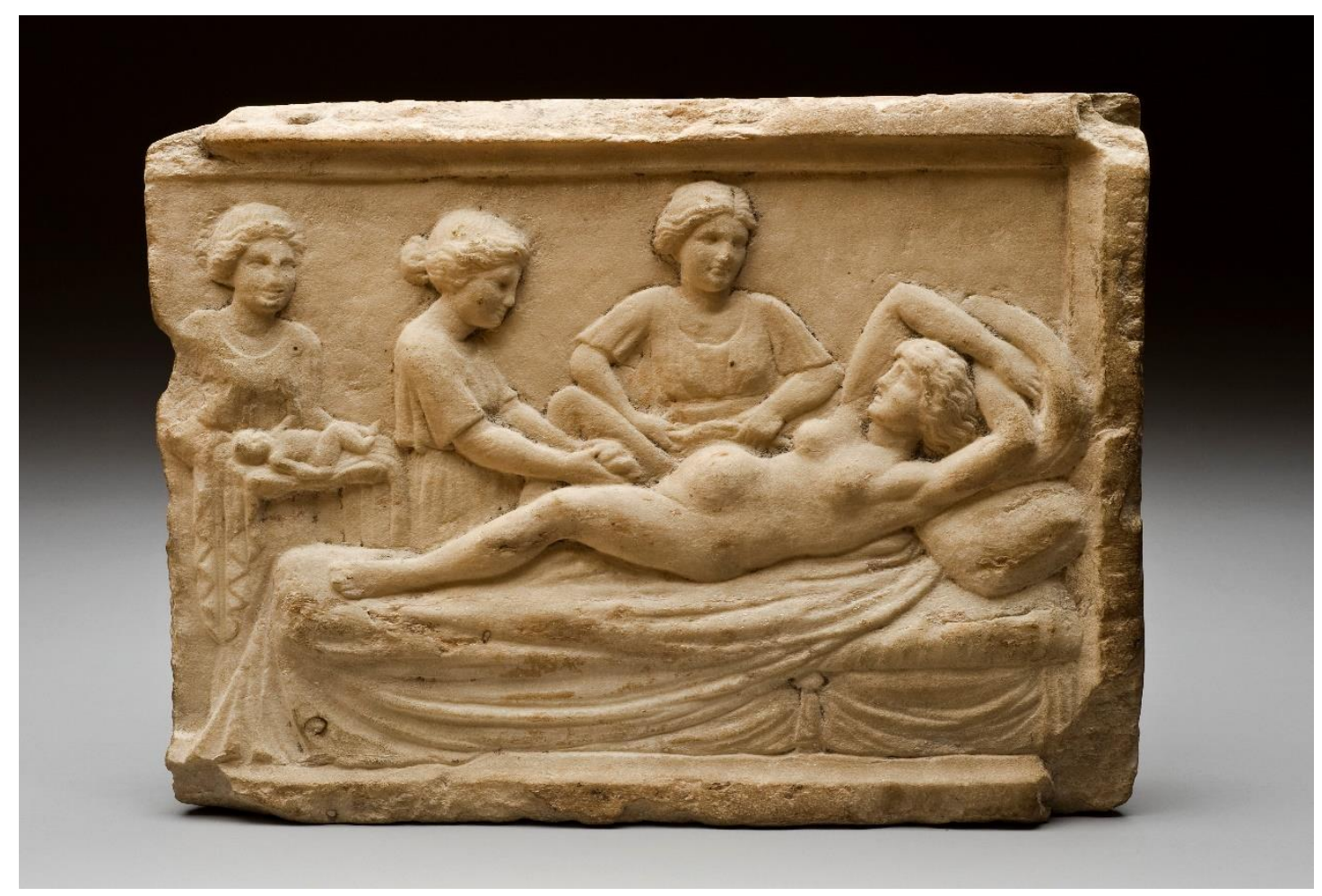

Fig 2

\footnotetext{
${ }^{3}$ Jean Towler and Joan Bramall, Midwives in History and Society (London: Croom Helm, 1986), p. 9 ${ }^{4}$ Rebecca Flemming, Medicine and the Making of Roman Women (Oxford: Oxford University Press, 2000), p. 359
} 
A "good" midwife, as described by Soranus of Ephesus, an important gynecologist during antiquity, in the 2nd century, in his work, Gynecology, is

"A suitable person... (who) must be literate to be able to comprehend the art through theory too. She must have her wits about her so that she may easily follow what is said and what is happening. She must have a good memory to retain the imparted instructions (for knowledge arises from memory of what has been grasped). She must love work, to preserve through all vicissitudes (for a woman who wishes to acquire such vast knowledge needs manly patience).

The most qualified midwife would be trained in all branches of therapy. She should be able to prescribe hygienic regulations for her patients, observe the general and individual features of the case, give advice by recalling from previous knowledge what medical decisions would work in every case and to be reassuring to her patients. It is not necessary for her to have had a child to deliver another woman's child, but it is good if she has been in labor to enhance sympathy with the mother.

To obtain good midwifery habits, she will be well disciplined and always sober, have a quiet disposition sharing many life secrets, must not be greedy for money, be free of superstition to not overlook salutary measures, keeping her hands soft by staying away from wool-working as this may harden her hands and use ointments to acquire softness. She too needs to be respectable, the people of the household will have to trust her within their household, may not be handicapped in the performance of her work. Long and slim fingers with short nails are necessary to touch deep-lying inflammation without causing too much pain. Midwives that acquire of all these will be the best midwives..." ${ }^{5}$

Soranus' instructions constituted a sort of textbook for midwives but at the same time, he manifests the great importance of their role and the high social status they enjoyed.

\footnotetext{
${ }^{5}$ Mary R. Lefkowitz and Maureen B. Fant, Women's Life in Greece and Rome (Baltimore, Maryland,
} 2005), 265 
Pliny, another well-known physician from this time, cherished nobility and a quiet, subtle disposition in a midwife ${ }^{6}$.

In both ancient and contemporary Greek 'Maia' is the name for a midwife?. Maia (/'mer.ə/ or /'mar.ə/; Greek: Maĩa; Latin: Maia), in ancient Greek mythology, is the oldest of the Pleiades, the mother of Hermes (Fig. 3).

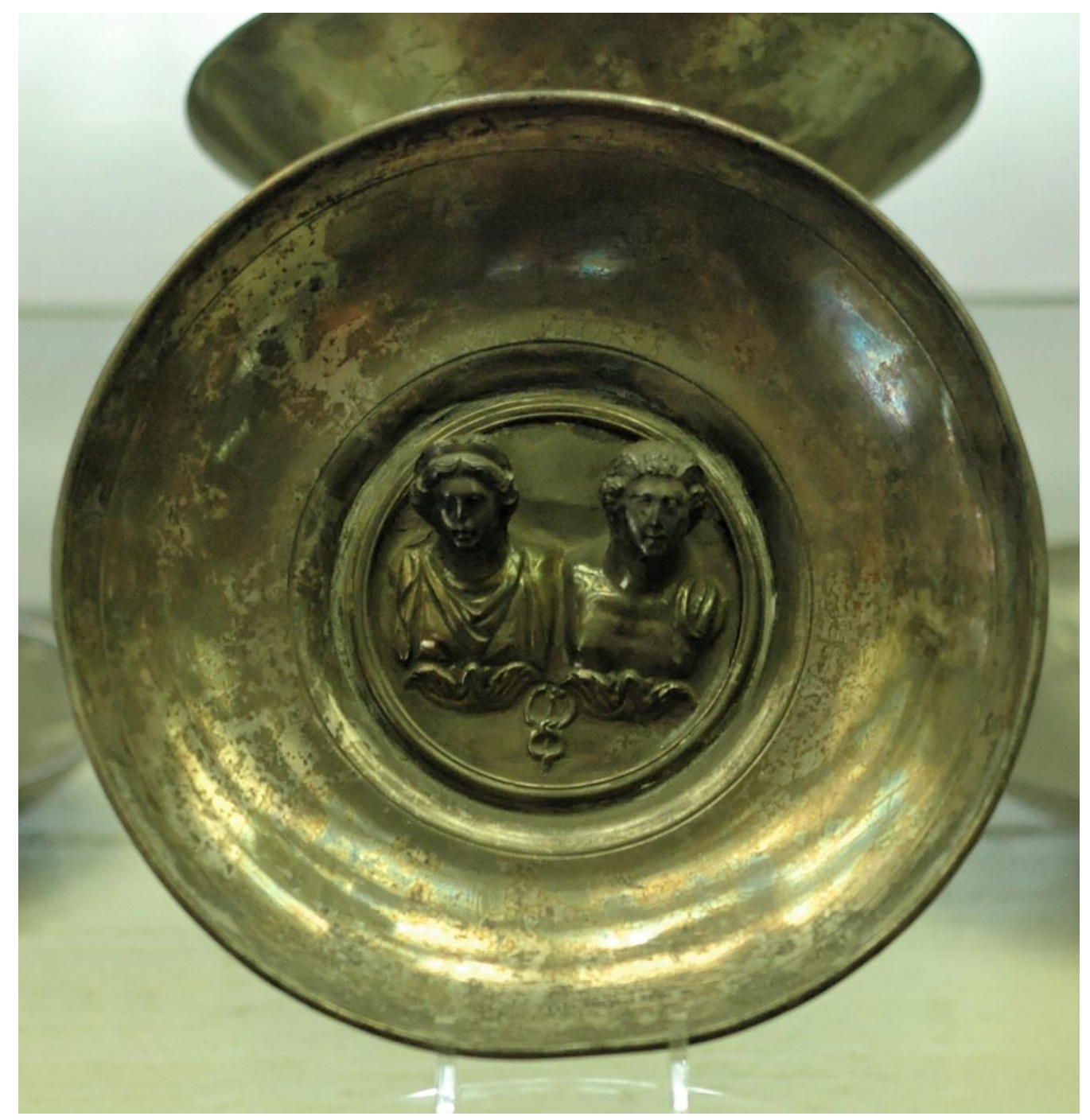

Fig 3

The Pleiades were the sisters of Calypso, Hyas, the Hyades, and the Hesperides. The Pleiades (/'plar.ədi:z, 'pli:ədi:z/; Greek: $\Pi \lambda \varepsilon\llcorner a ́ \delta \varepsilon \varsigma$ [ple:ádes]), are companions of goddess Artemis, the seven daughters of the titan Atlas and the sea-nymph Pleione

\footnotetext{
${ }^{6}$ Ralph Jackson, Doctors and Diseases in the Roman Empire (Norman: University of Oklahoma Press, 1988), p. 97

${ }^{7}$ Vivian Nutton, Ancient Medicine (Routledge, 2004), p. 101.
} 
who were born on Mount Cyllene (Fig. 4). The Pleiades were nymphs in the train of Artemis and were translated to the night sky as a cluster of stars. Along with the seven Hyades were called the Atlantides, Dodonides, or Nysiades, nursemaids and were teachers to the infant Dionysus. Maia is depicted on a chariot travelling to the

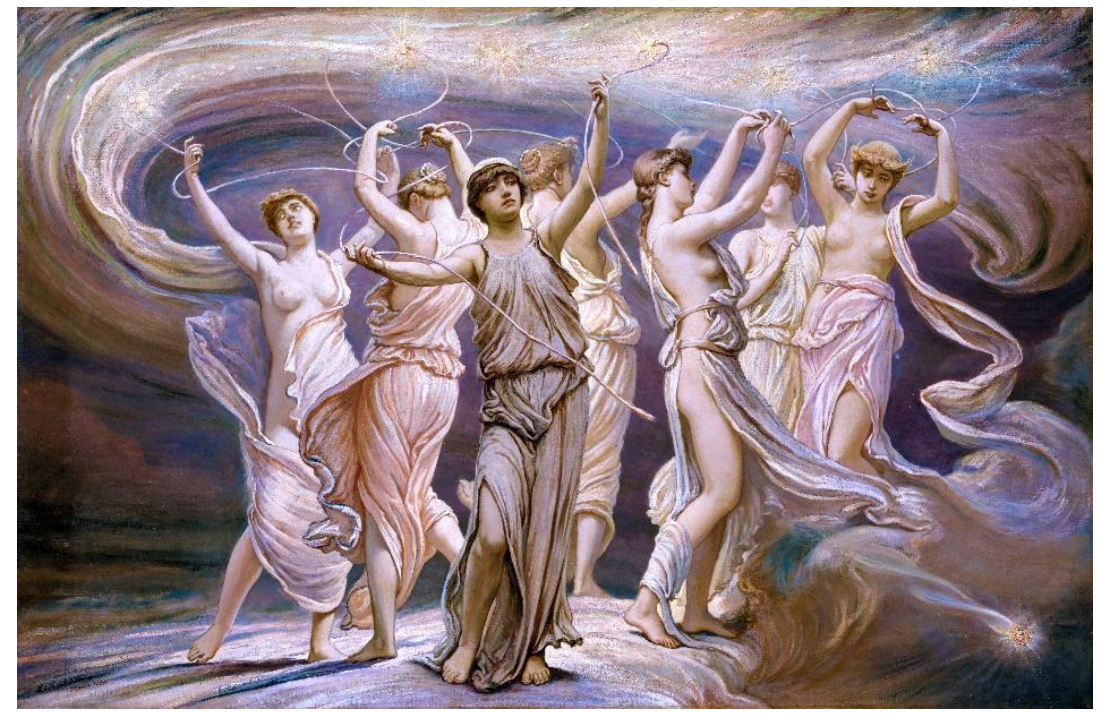

Fig 4

wedding of Peleas and Thetis with her son Hermes, on the famous François vase, a large Attic volute krater decorated in the black-figure style ca. 570-565 BCE (Fig. 5).

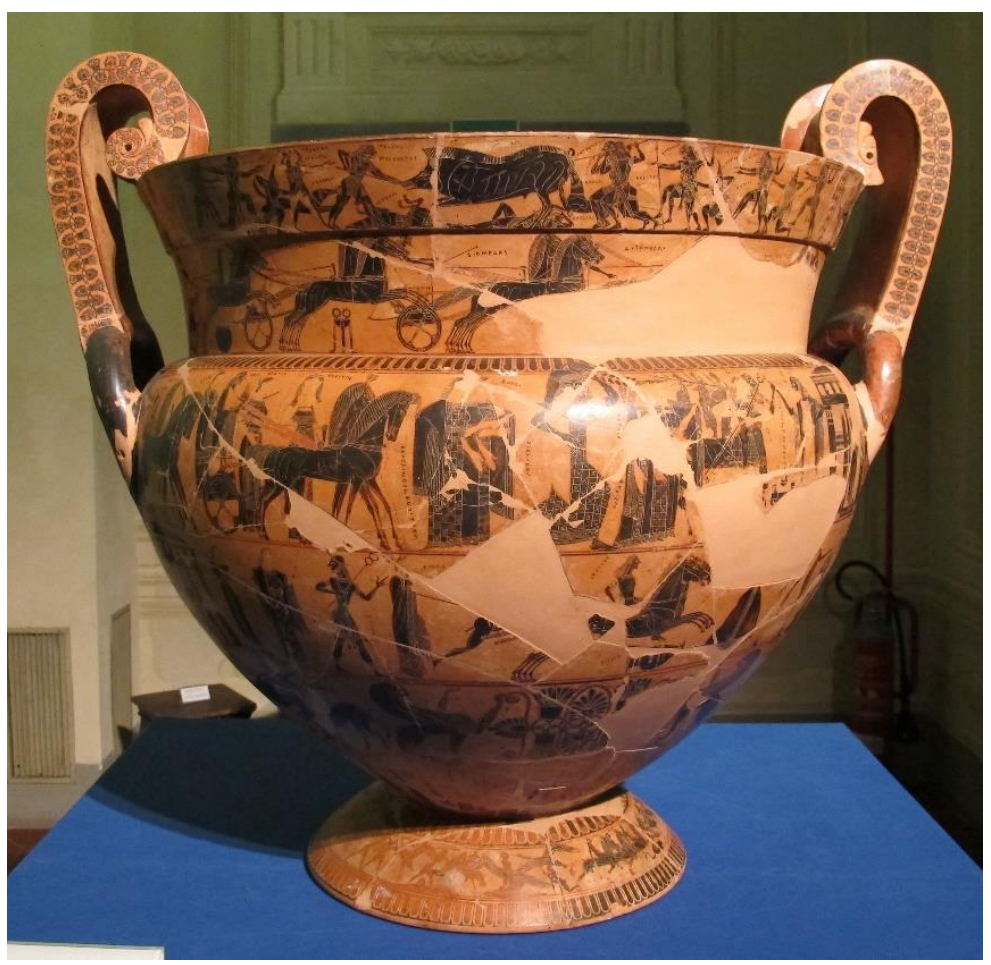

Fig 5 
In ancient Greek mythology, the work of the protection of women in labour was assigned to goddess Hera. Hesiod (c. 700 BC) described Eileithyia as a daughter of Hera

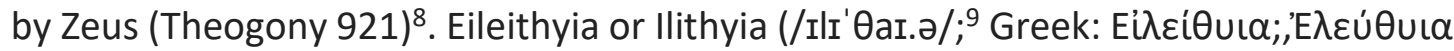

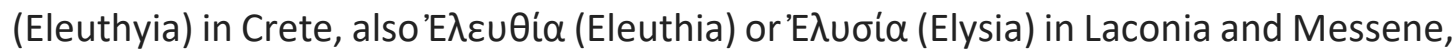
and 'E $\lambda \varepsilon \cup \theta \omega$ (Eleuthō) in literature) was the Greek goddess of childbirth and midwifery ${ }^{10}$. It is possible that her cult is related with the cult of Eleusis ${ }^{11}$. Her name means "she who comes to aid" or "relieve" from the Greek word elêluthyia. Her Roman equivalent was Lucina ("Light spreader") or Natio ("Birth"). In art she was depicted as a woman carrying a torch. At times her arms were raised in the air to bring the child to the light of life.

According to F. Willets, "The links between Eileithyia, an earlier Minoan goddess, and a still earlier Neolithic prototype are, relatively, firm. The continuity of her cult depends upon the unchanging concept of her function. Eileithyia was the goddess of childbirth; and the divine helper of women in labour has an obvious origin in the human midwife." To Homer, she is "the goddess of childbirth"12. The Iliad pictures Eileithyia alone, or sometimes multiplied, as the Eileithyiai:

And even as when the sharp dart striketh a woman in travail, [270] the piercing dart that the Eilithyiae, the goddesses of childbirth, send-even the daughters of Hera that have in their keeping bitter pangs; [15]

- lliad 11.269-272

In the Orphic Hymn to Prothyraeia, the association of a goddess of childbirth as an epithet of virginal Artemis, making the death-dealing huntress also "she who comes to the aid of women in childbirth," (Graves 1955 15.a.1), would be inexplicable in purely Olympian terms:

\footnotetext{
8 Theogony 912-923

${ }^{9}$ Joseph Emerson Worcester, A comprehensive dictionary of the English language, Boston, 1871, $\mathrm{p}$. 480 , rule 3, where he notes the word has four syllables as in Greek and Latin, "not I-lith-y-i'-a as in Walker" (e.g. Walker and Trollope, A key to the classical pronunciation etc., London, 1830, p. 123). ${ }^{10}$ Gantz, pp. 82-83

${ }^{11}$ F.Schachermeyer(1967). Die Minoische Kultur des alten Kreta.W.Kohlhammer Stuttgart. pp. 141-142

${ }^{12}$ Homer, Iliad 16.187, 19.103.
} 
When racked with labour pangs, and sore distressed

the sex invoke thee, as the soul's sure rest;

for thou Eileithyia alone canst give relief to pain,

which art attempts to ease, but tries in vain.

Artemis Eileithyia, venerable power,

who bringest relief in labour's dreadful hour.

- Orphic Hymn 2, to Prothyraeia, as translated by Thomas Taylor, 1792.

Eileithyia was born in a cave near Knossos, Crete, a cave mentioned in Book 19 of Homer's Odyssey and became the most important place of worship for her. Inside the cave, the stalactites and stalagmites symbolize her double actions of inducing labour and delaying it, as she did with the birth laboring of Alcmene. The cave stands for the darkness of the womb and the passage out of it conveys a connection to the birth process.

Midwives also aided abortions, as sited by Plato:

"And furthermore, the midwives, by means of drugs [149d] and incantations, are able to arouse the pangs of labor and, if they wish, to make them milder, and to cause those to bear who have difficulty in bearing; and they cause miscarriages if they think them desirable".

- Plato: Theaetus (excerpts)

On an Attic Black Figure amphora depicting the birth of goddess Athena, dating ca. 545 - 535 B.C.E., Eileithyia along with Hera, Aes and Hermes witnesses the birth of Athena and midwives the child with two high raised arms (Fig. 6). The goddess springs from the head of Zeus who is sitting on a throne sculpted with two horses, holding a scepter in one hand and a lightning-bolt in the other. Hermes is wearing a peaked traveller's cap, a chlamys, "winged" boots, and is holding a herald's wand in his hand. 
Hera is standing opposite Maia crowned with a mitra, lifting her hand, while Ares is depicted in his gear as a warrior, holding a shield decorated with the image of a tripod.

In ancient Roman mythology, Maia ${ }^{13}$ embodied the concept of growth ${ }^{14}$, as her name was thought to be related to the comparative adjective maius, maior "larger, greater"15. The word 'Maia' may also derive from the apocope of the word " $\mu \alpha-\tau \eta$ $\rho=\mu \eta \dot{\tau \eta} \rho$ (mother), $\mu \alpha \nu \eta=\mu \eta \tau \varepsilon \rho \alpha \eta /$ mother earth. Since mothers breastfeed, the midwife was related to the idea of the caretaker and the nurse ${ }^{16}$.

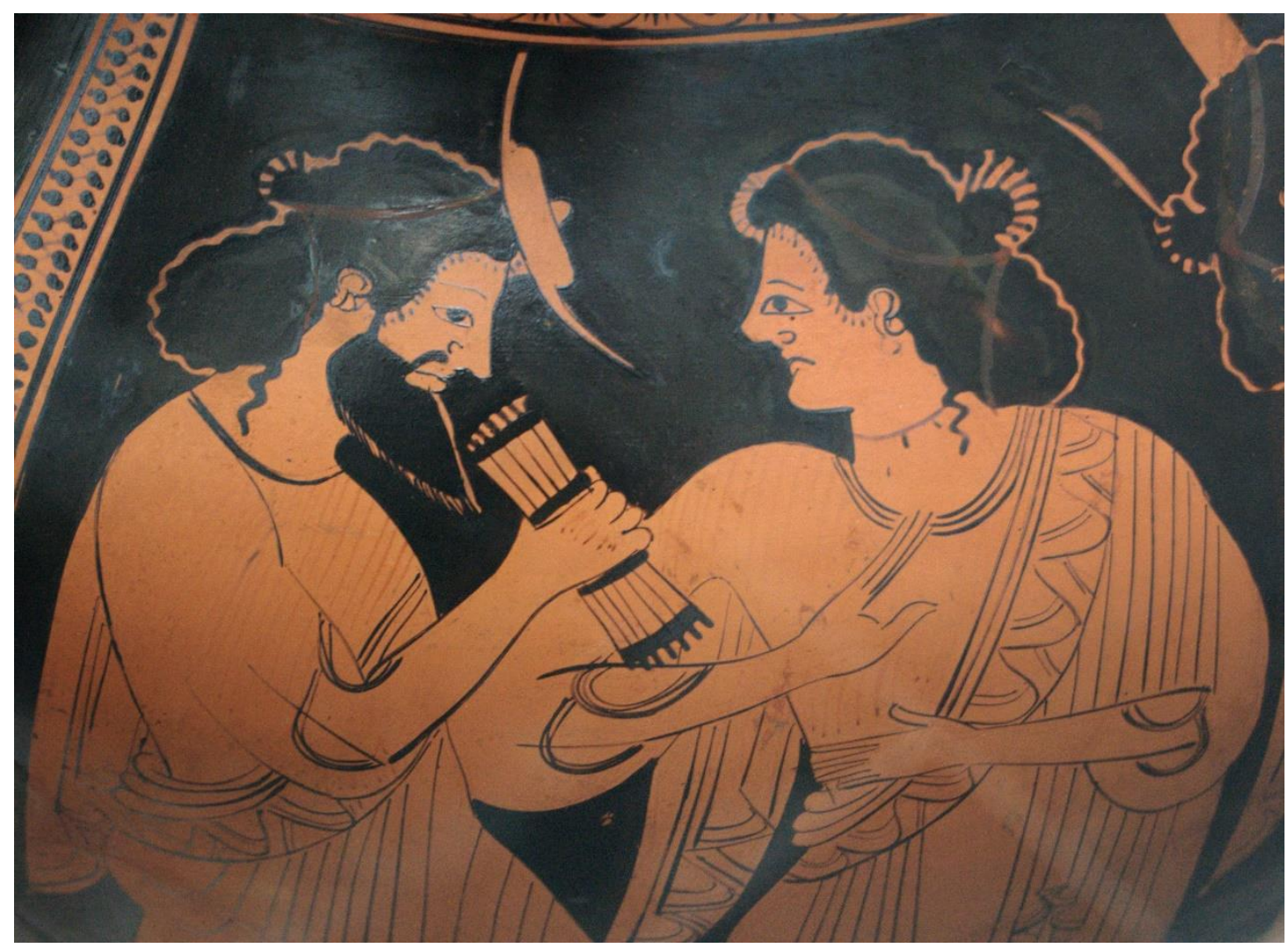

Fig 6

Agnodice (c. 4th century BCE) or Agnodike (Gr. Apvodíkn) was the first, most likely legendary, midwife or physician mentioned among the ancient Greeks (Fig. 7). The

\footnotetext{
${ }^{13}$ The month of May (Latin Maius) was supposedly named for Maia.

${ }^{14}$ Robert Turcan, The Gods of Ancient Rome: Religion in Everyday Life from Archaic to Imperial Times, Routledge, 2001, p. 70.

${ }^{15}$ Initially, Maia may have been a homonym independent of the Greek Maia, whose myths she absorbed through the Hellenization of Latin literature and culture. (Pierre Grimal, The Dictionary of Classical Mythology, Blackwell, 1996, p. 270 (originally published in French in 1951)

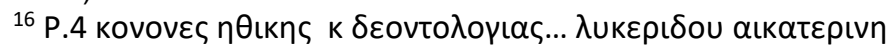


Roman author Gaius Julius Hyginus in his Fabulae tells her story and how she studied under Herophilus, a famous Greek physician, in Alexandria and later practiced midwifery and medicine in Athens disguised as a man, since women at the time were not allowed to practice medicine ${ }^{17}$.

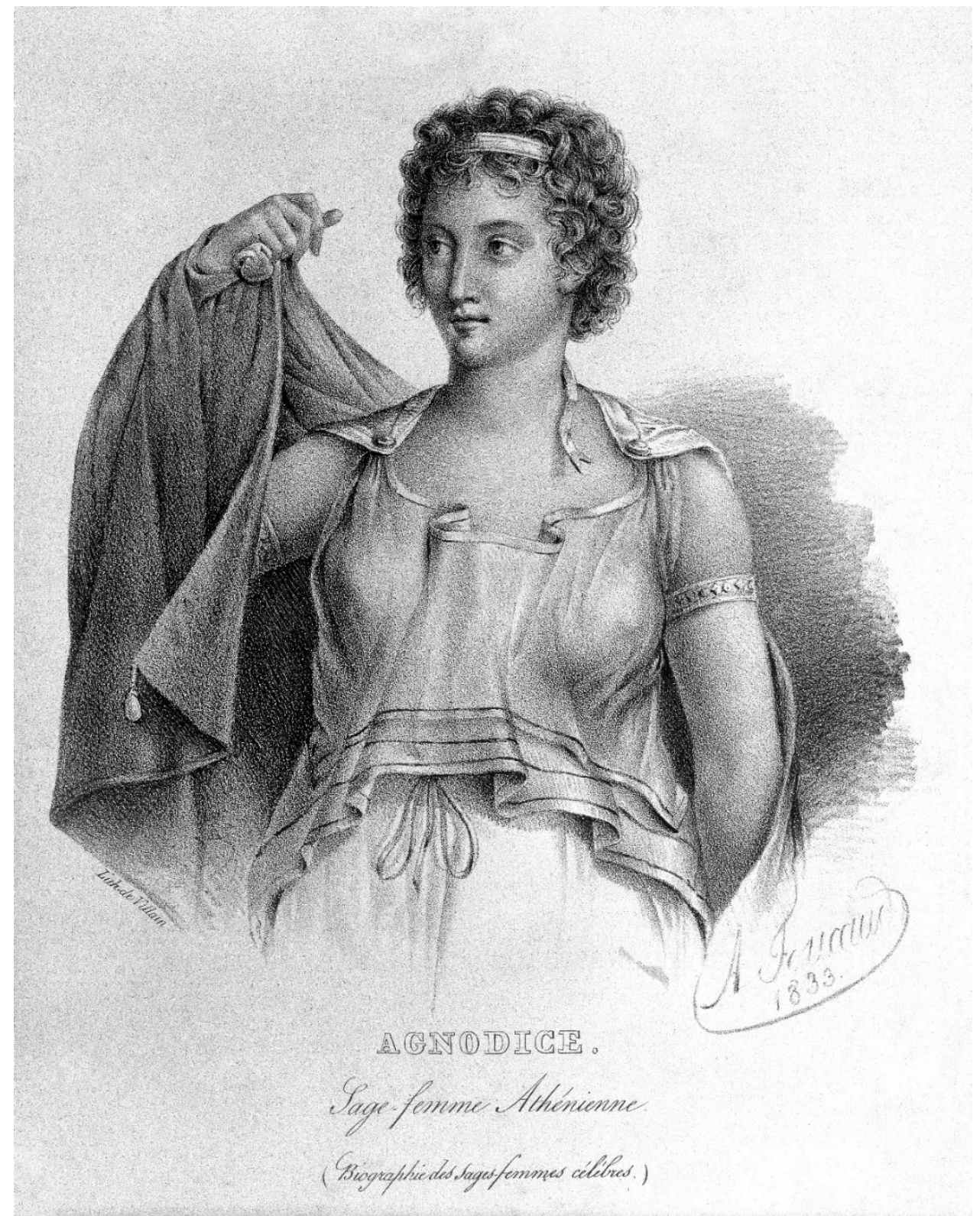

Fig 7

${ }^{17}$ Greenhill, William Alexander (1867). "Agnodice". In Smith, William. Dictionary of Greek and Roman Biography and Mytholoyy. 1. Boston: Little, Brown and Company. p. 74. 
Midwives were known by many different titles in antiquity, ranging from iatrinē (Gr. nurse), maia (Gr., midwife), obstetrix (Lat., obstetrician), and medica (Lat., doctor) ${ }^{18}$. Obstetrix is the Latin word for midwife: it is thought to derive from obstare (to stand before), because the attendant stood in front of the woman to receive the baby. Only in the 20th century did the subject, taught in medical schools, change its name from "midwifery" to "obstetrics," perhaps because a Latin name seemed more academic than the Anglo-Saxon, derived from mid, "with," and wyf, "woman"19.

In ancient Rome midwives enjoyed an equally high social and financial status as doctors $^{20}$. One rare such occasion is the case of Salpe of Lemnos, who wrote on women's diseases and was mentioned several times in the works of Pliny ${ }^{21}$

Remedies offered by midwives to the new mothers were usually strange concoctions made up to heal them. From the Hippocratics, "the urine of men or bulls, tar water, chaste tree (Vitex agnuscastus), pomegranates, cantharides, or castor oil" was a common folk, yet bizarre, mixture utilized for gynecological maladies ${ }^{22}$.

According to Valerie French ${ }^{23}$, Pliny wrote of common medical practices that would today be considered absurd, particularly when applied as an aid of child birth. Among the practices French mentions, are the placing of a hyena's left or right foot on the shoulder of the mother in labor, sneezing for relief of a difficult labor, the use of wine.

In ancient times childbirth was considered risky, agonizing, and terrifying. Women were generally helped through this process by both mothers and midwives. They prayed and made offerings to Eileithyia, as well as to Artemis, patron of women's lifecycles, hoping that both mother and child would survive the process (Fig. 8).

\footnotetext{
${ }^{18}$ Rebecca Flemming, Medicine and the Making of Roman Women (Oxford: Oxford University Press, 2000), pp. 421-424

19 Liubov, B.N., Midwifery in ancient and modern times, 2017, p.4,

${ }^{20}$ Valerie French, "Midwives and Maternity Care in the Roman World" (Helios, New Series 12(2), 1986), pp. 69-84

${ }^{21}$ Ralph Jackson, Doctors and Diseases in the Roman Empire (Norman: University of Oklahoma Press, 1988), p. 97

${ }^{22}$ Camran Nezhat, Farr Nezhat, and Ceana Nezhat. "Endometriosis: Ancient Disease, Ancient Treatments." Fertility and Sterility 98, 6 (2012): 6-7.

${ }^{23}$ Valerie French, "Midwives and Maternity Care in the Roman World" (Helios, New Series 12(2), 1986),
} 


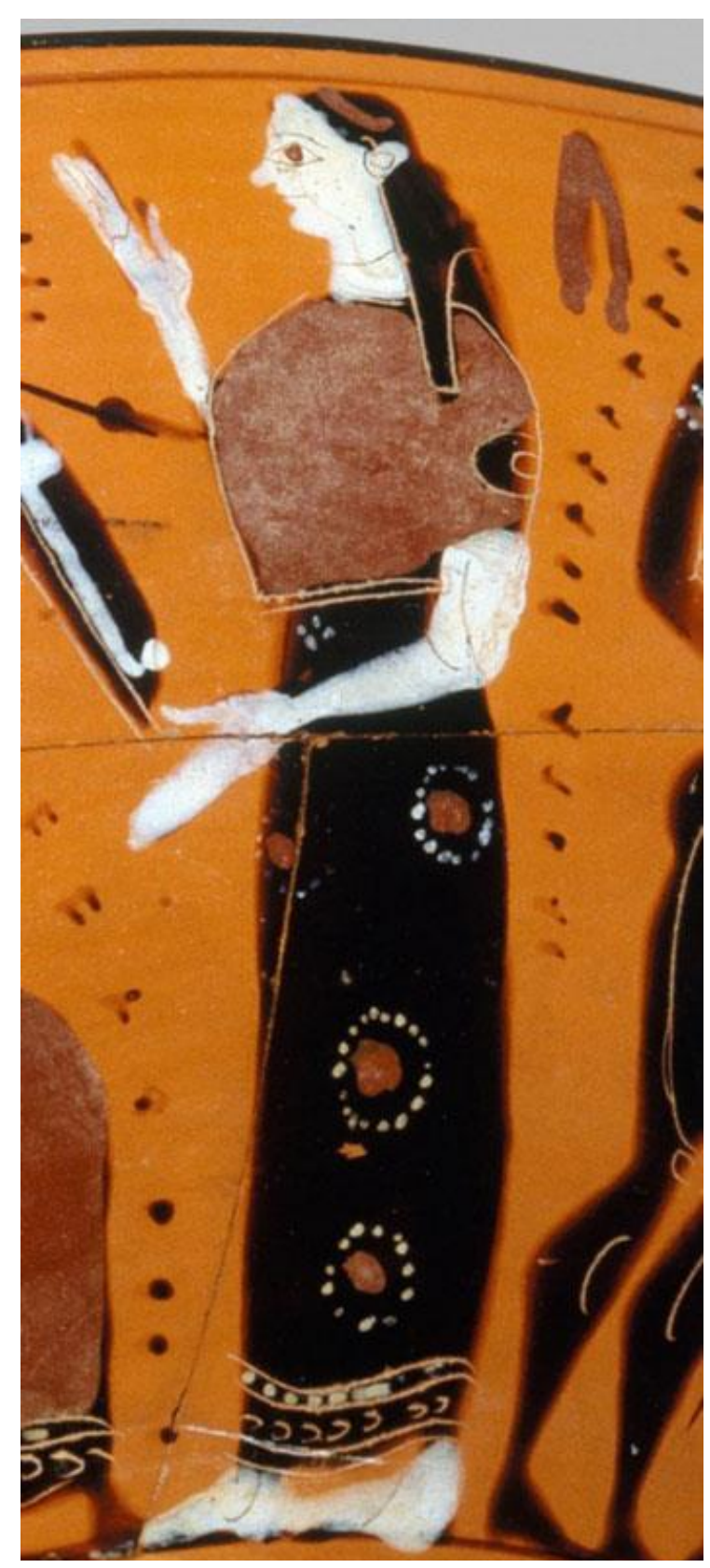

Fig 8

In most of the world mythologies the universe was created through birth and there is an abundance of deities associated with it, as well as fertility gods and goddesses or deities who help protect pregnant women, babies and children. Fertility rites may accompany their worship. In Greek mythology alone, there are at least 15 such goddesses and deities: Aphaea, Aphrodite, Artemis, Cybele, Demeter, Dionysus, Eros, Gaia, Hera, Ilithyia, (also called Eileithyia), Phanes, Rhea.

Another beautiful example of Eileithyia we find on a small vase ca. 370 B.C.E. On a stool seated is Leto, the mother of Apollo and Artemis, and is shown while giving birth to her children, on the island of Delos. The experience of the labour is depicted on her face and she is holding on to a palm tree as a means to help herself. Before her is Athena and Eileithyia is behind her (Fig. 9).

Artemis was also thought of as the first midwife in Greek mythology since, according to the myth, she was born before her brother Apollo and, witnessing her mother's painful labour, helped her deliver her son. Artemis was worshipped as the patron of childbirth and children. In an engraving of the $16^{\text {th }}$ century, Leto is depicted giving birth to her children on the island of Delos (Fig. 10).

Greek myths are awashed with descriptions of labours of ancient heroes and gods. Extraordinary medical cases such as extracorporeal fertilization, superfecundation, 
ectopic pregnancy, preterm labour, prolonged pregnancy and Caesarean section are among the themes that occupied mythology and therefore the imagination and art of people thousands of years ago ${ }^{24}$.

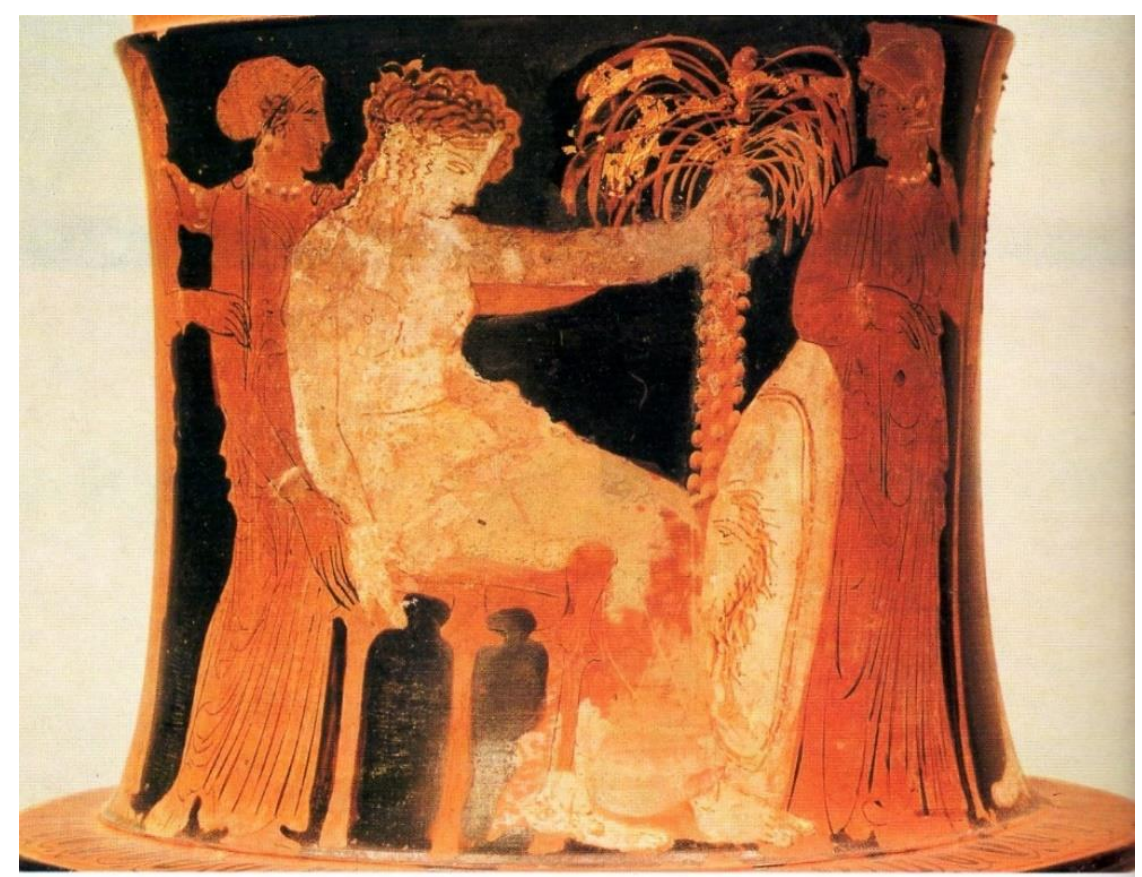

Fig 9

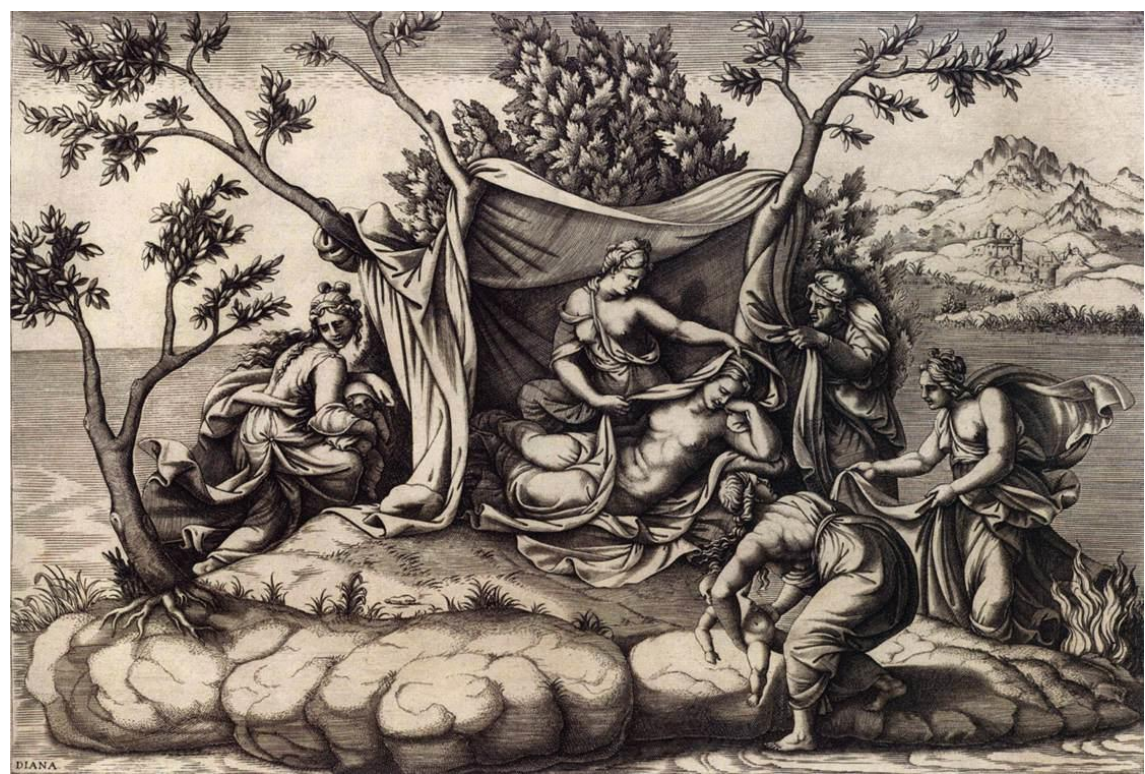

Fig 10

\footnotetext{
${ }^{24}$ Lavazzo, C., Trompoukis C, Sardi T, Falagas ME., Conception, complicated pregnancy, and labour of gods and heroes in Greek mythology. (Cited 10/8/2017) Available from https://www.ncbi.nlm.nih.gov/pubmed/18644217
} 


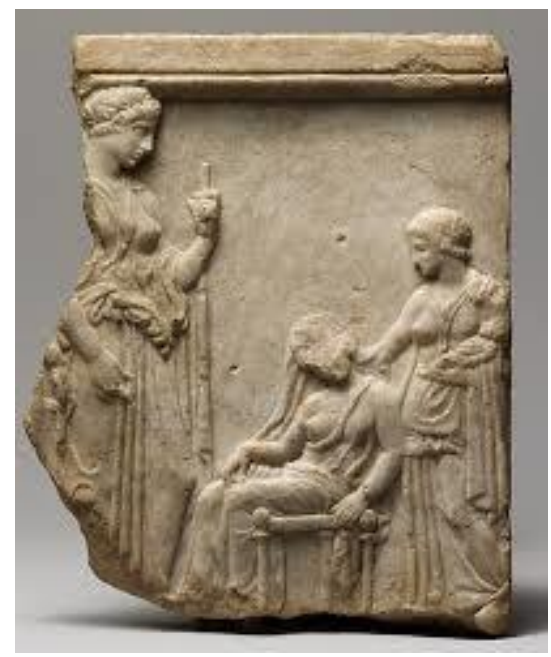

In ancient Greece, unlike modern times, giving birth was associated with miasma. In a marble votive relief fragment of the late $5^{\text {th }}$ century $B C E$, found at the Metropolitan Museum of Art, New York, a goddess, a mother, a midwife and an infant are shown (Fig. 11).

Fig 11

"To the left is a stone sculpture showing a woman who has just given birth and presumably prepares to nurse, her right breast exposed. The mantle that is draped over the new mother's head refers to the miasma, or state of pollution, that was believed to attend a woman following childbirth. The distress of the woman is clearly apparent as she slumps forward and grips the seat for support. A nurse stands behind her holding the newborn baby. The size of the figure in front of the mother indicates she is a goddess, most likely Eileithyia, goddess of childbirth, or Hygieia, goddess of good health, cleanliness, and sanitation. Thus, the relief may be a votive dedication" 25 .

The acceptance of the midwifery profession in ancient Greece is also noticeable through the examination of funerary steles, the best known of which is the stele of Fanostrati (350 B.C.E) bearing the inscription:

"Here lies Fanostrati, Midwife and Doctor. She never caused pain to anyone and everybody mourned her death".

On the funerary stele the figure of Fanostrati is carved in relief and is surrounded by children (Fig. 12). Driven from the fact that she is referred to as a doctor we can conclude that Fanostrati was a prominent citizen of the time enjoying respect and a high social status.

\footnotetext{
${ }^{25}$ Ancient Gynecology, (Cited 2/7/2017) Available from http://exhibits.hsl.virginia.edu/antiqua/gynecology/
} 


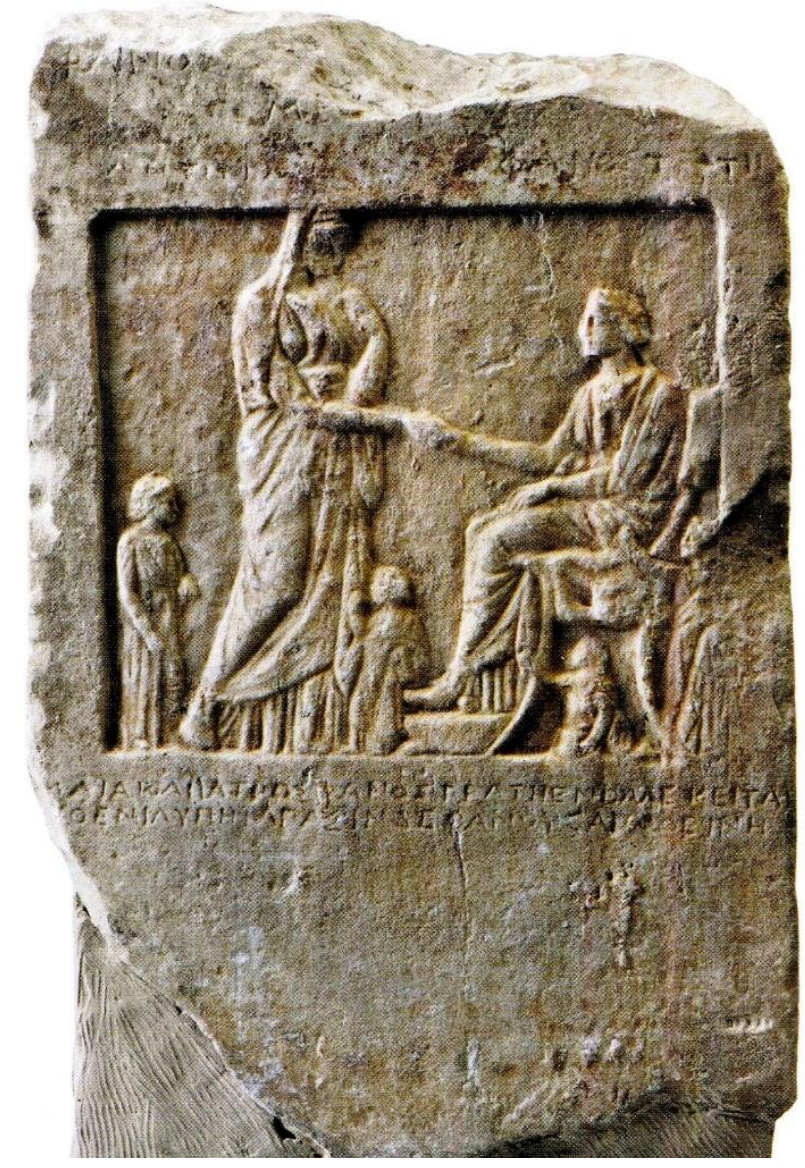

Fig 12

An instance of a midwife being present at the reception of a dead woman we find in a Greek Attic funerary stele ca. $350-330$ BCE. It is showing a seated woman who died in childbirth bidding farewell to her husband, mother and newborn's nurse (Fig. 13).

In the Byzantine empire there was a particularly well-developed system of health care which formed the basis of our modern ones. There were hospitals and other institutions in every corner of the empire which were either under state or church control servicing both the

Byzantines and foreigners.

Among these foundations there were also maternity hospitals ("^охоко $\mu \varepsilon i \alpha$ ") where midwives and doctors took care of pregnant women at all stages of pregnancy and the period after that. There were also unofficially trained midwives who worked following practices steeped in superstition, a kind of mixture comprising science and popular / folk medicine.

The greatest majority of byzantine iconography revolves around religious themes, among which the most popular was the nativity of Christ. In byzantine nativity scenes the presence of midwives was common and well received although based on apocryphal gospels. Midwives were present at such icons and bathed baby Jesus. They are depicted as ordinary

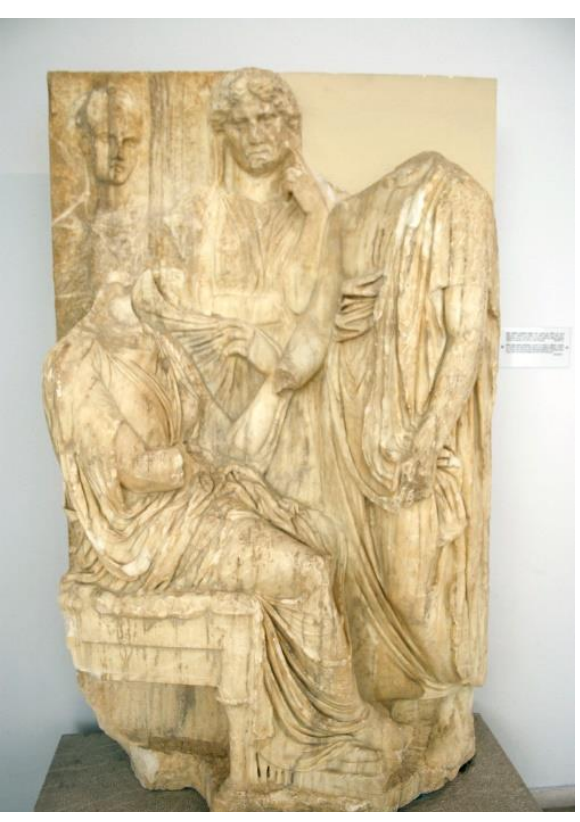

Fig 13 
women of their time without any idealization, in smaller scale compared to the other figures present at the nativity scene, always wearing a head cover, either plain or with designs, which at times leaves part of their hair uncovered falling on their shoulders or covers it fully. The element of the head cover conveys their status as well-respected members of the byzantine society since it was usually used in the depiction by elderly women and saints. The complexity or luck of designs on the head cover also suggests social status.

In the best example of such iconography, the icon of the nativity of Christ from the

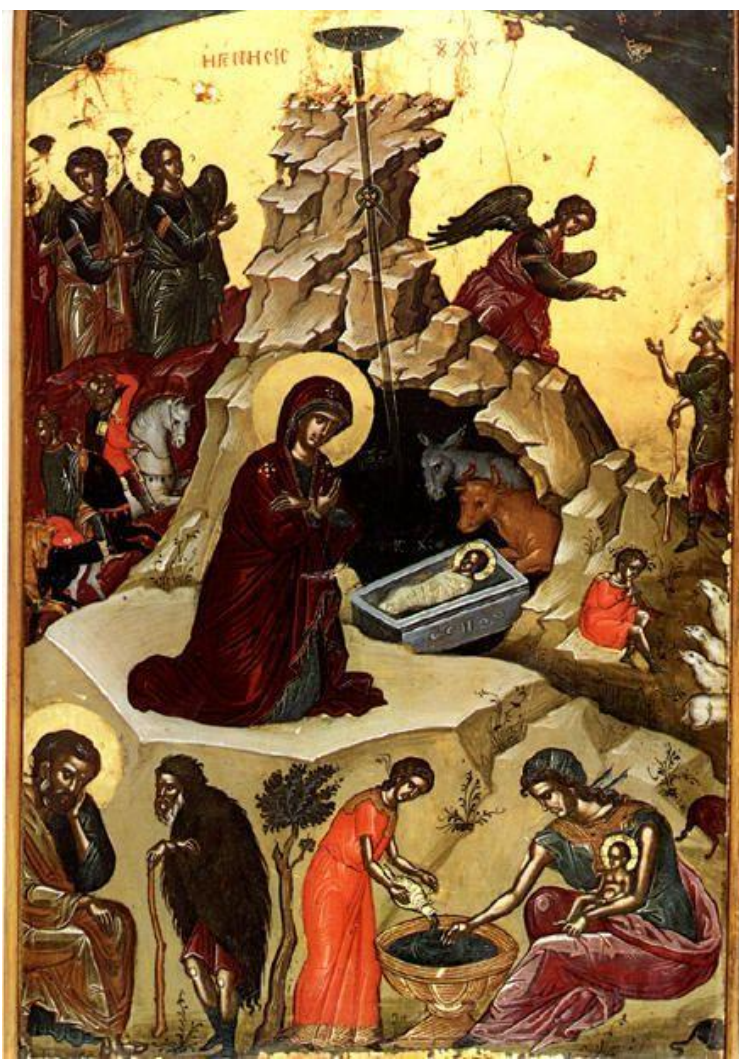
Stavronikita Monastery (16 ${ }^{\text {th }}$ century), we can observe that the midwives, the virgin Mary and the Holy Spirit are aligned according to a scale that suggests their status. The midwives are situated on the earthly level, the Madonna in the middle and the supernatural Holy Spirit on the transient level. Perhaps, the artist placed the figures in such a way as to underline their spiritual importance (Fig. 14)

Fig 14

The presence of midwives in the nativity scene of Jesus attests to the high status they enjoyed in byzantine society. They are bathing Jesus. What greater proof of that?

Midwives have always assisted women and have mediated for the new life to surface. Through this concise visit to the image and role of the midwife in ancient Greek and Byzantine art in context, midwives were well-respected figures in society enjoying a high social status, offering their service to mothers and children. Midwifery is a perfect 
combination of craft and science, the most intimate and the closest profession to the mystery of life. It comes as a surprise that, although well documented in literature, the cinema and scientific treatises, there have been such few depictions in art. It seems that the focal point of artists since antiquity has been the portrayal of pregnancy and not of those aiding the pregnant women. Nevertheless, through this brief discussion of midwives in art one can definitely state that midwives occupy a limited yet important place in it.

\section{Bibliography}

Ancient Gynecology, (Cited 2/7/2017) Available from http://exhibits.hsl.virginia.edu/antiqua/gynecology/

Bacon, J., L., M.D. (2009). "Women in Obstetrics and Gynecology: Appreciating the Past, Looking to the Future." South Atlantic Association of Obstetricians and Gynecologists

Clark, G., (1981). Roman Women. Greece and Rome 28.02 : 193-212

"Definition of Midwifery". Encyclopedia Britannica. Retrieved 7/10/ 2018.

Engels, D., (1980). The Problem of Female Infanticide in the Greco-Roman World, Classical Philology 75.2

Flemming,R., (2000). Medicine and the Making of Roman Women, Oxford: Oxford University Press

French, V., (1986). Midwives and Maternity Care in the Roman World, Helios, New Series $12(2)$

Greenhill, W. A., (1867). Agnodice. In Smith, W., Dictionary of Greek and Roman Biography and Mythology. 1. Boston: Little, Brown and Company

Grimal, P., (1996). The Dictionary of Classical Mythology, Blackwell

Hippocrates, On the Generating Seed and the Nature of the Child 4-7, 13, 30.4

Homer, lliad 16.187, 19.103 
"International Definition of the Midwife". International Confederation of Midwives. Retrieved 7/10/2018.

Jackson, R., (1988). Doctors and Diseases in the Roman Empire, Norman: University of Oklahoma Press

Lefkowitz, M.R., Fant, M.B.,(2005). Women's Life in Greece and Rome, Baltimore, Maryland

Lavazzo, C., Trompoukis C, Sardi T, Falagas ME., Conception, complicated pregnancy, and labour of gods and heroes in Greek mythology. (Cited 10/8/2017) Available from https://www.ncbi.nlm.nih.gov/pubmed/18644217

Liubov, B.N., (2017). Midwifery in ancient and modern times, B.N. Publication House, Israel

Lurie, S., (2005). Obstetrics and Gynecology: A History and Iconography. Review of Obstetrics and Gynecology: A History and Iconography Revised Third Edition of Iconographia Gyniatrica, by Harold Speert. New England Journal of Medicine 352.8

Nezhat, C., Nezhat, F., Nezhat, C.,(2012). "Endometriosis: Ancient Disease, Ancient Treatments." Fertility and Sterility 98, 6

Pomeroy, S. B., (1995). Goddesses, Whores, Wives, and Slaves. New York: Schocken

Schachermeyer, F., (1967). Die Minoische Kultur des alten Kreta.W.Kohlhammer Stuttgart

Theogony, 912-923

Towler, J., Bramall, J., (1986). Midwives in History and Society, London: Croom Helm

Todman, D., (2007). Childbirth in Ancient Rome: From Traditional Folklore to Obstetrics. The Australian and New Zealand Journal of Obstetrics and Gynaecology 47.2

Turcan, R., (2001). The Gods of Ancient Rome: Religion in Everyday Life from Archaic to Imperial Times, Routledge 
Nutton, V., (2004). Ancient Medicine, Routledge

Wickkiser, Bronwen L., (2008). Asklepios, Medicine, and the Politics of Healing in Fifthcentury Greece: Between Craft and Cult. Baltimore: Johns Hopkins University Press

Worcester, J.E., (1871). A comprehensive dictionary of the English language, Boston

\section{List of pictures}

\section{All the pictures belong to the public domain}

Figure 1. Constantin Brancusi. The Newborn. Version I, 1920, MOMA

Figure 2. Marble plaque depicting parturition or birthing scene. Ostia Antica, Roma, Lazio, Italy

Figure 3. Mercury and Maia inside a silver cup dedicated by the freedman P. Aelius Eutychus (late 2nd century AD)

Figure 4. Elihu Vedder, The Pleiades, 1885, Metropolitan Museum of Art

Figure 5. Attic Black-Figure Volute-Krater, known as the Francois vase, ca. 570-565 BCE.

Figure 6. Hermes and Maia, detail from an Attic red-figure amphora (c. 500 BC)

Nikoxenos Painter, Staatliche Antikensammlungen

Figure 7. Agnodice, engraving, Gallery:

https://wellcomeimages.org/indexplus/image/L0016719.html

Figure 8. Eileithyia, Athenian black-figure kylix C6th B.C., Metropolitan Museum of Art Figure 9. The birth of Apollo and Artemis,c. 370 BCE, National Museum, Athens

Figure 10. Leto Giving Birth to Apollo and Diana on the Island of Delos, 1560s, National Gallery of Art, Washington

Figure 11. Marble votive relief fragment of goddesses, mother, nurse, and infant, late 5th century BCE, New York, Metropolitan Museum of Art 
Figure 12. Greek Attic funerary stele, showing a seated woman who died in childbirth bidding farewell to her husband, mother and newborn's nurse. Around 350 to 330 BCE.

Figure 13. Greek Attic funerary stele of Fanostrati, c. 350 BC, National Archaeological Museum,Athens

Figure 14. Theophanes the Cretan, the Nativity of Jesus, Stavronikita Monastery, 1546, Monastery on Mount Athos 